\title{
Interfirm Partnerships and Organizational Innovation: Study of SMEs in the Automotive Sector
}

\author{
Mário Franco ${ }^{1, *(1)}$ and Heiko Haase ${ }^{2(1)}$ \\ 1 CEFAGE-UBI Research Center, Department of Management and Economics, University of Beira Interior, \\ Estrada do Sineiro, 6200-209 Covilhã, Portugal \\ 2 Center for Innovation and Entrepreneurship, University of Applied Sciences Jena, 07745 Jena, Germany; \\ heiko.haase@fh-jena.de \\ * Correspondence: mfranco@ubi.pt
}

Received: 13 November 2020; Accepted: 14 December 2020; Published: 15 December 2020

\begin{abstract}
This study aims to analyze the influence that interfirm partnership motives can have on the implementation of organizational innovation activities. To achieve this aim, a quantitative cross-sectional research design was adopted, surveying owners-managers of small and medium-sized enterprises in the automotive sector. Based on the empirical evidence, the study concludes that the motives for partnership formation are related to organizational innovation activities, but only partially. Of the four main factors for establishing interfirm partnerships ('Efficiency', 'Innovation and learning', 'Market opportunities', 'Technology and competition'), only the motives associated with the latter were shown to have a positive and significant influence on organizational innovation. Implications for theory and practice are also presented.
\end{abstract}

Keywords: SMEs; interfirm partnerships; organizational innovation; open innovation; technology; automotive sector

\section{Introduction}

The increasing demands of globalization, competition and consumers have made business environments very dynamic and progressively more competitive. Thus, organizations in a global economy are under constant pressure, facing rapid change in technologies and a high demand for new products and services. In this context, innovation can be considered as a central factor of firms' success. This is even more relevant for small and medium-sized enterprises (SMEs), which often try to assert themselves through innovations to compete with the large players and so as not to put their survival at risk [1]. In fact, many important innovations were identified from the SMEs context [2,3].

On the other hand, SMEs face some disadvantages, such as limited financial and personnel resources, as well as limited time to develop innovation practices (e.g., [4,5]) Therefore, these small firms can present a weak level of competitiveness compared to larger enterprises. The innovation environment that particularly affects SMEs is characterized by limited resources, liabilities of smallness [6], newness [7] and short reaction times to market changes [8]. In order to survive in this competitive environment and overcome their specific disadvantages, SMEs need to adapt though flexibility and new organizational formats, such as organizational innovations $[9,10]$, including partnerships with other firms.

The term 'partnership' covers a set of terminologies that are often interchangeably used in professional and academic publications [11]. More specifically, Culpan [12] elucidated the variety of terms such as strategic alliances, cooperative ventures, interfirm cooperation, collaborative ventures, coalitions and even joint ventures that describe the phenomenon. Altogether, the overlapping core within all these concepts is interfirm partnerships, so that this term will be used in the present paper. 
Partnerships are understood here as the interaction between independent firms, so as to attain joint or similar objectives when entering into the partnership [13].

On the other hand, despite no consensual definition of organizational innovation, some studies (e.g., [14]) defined this type of activity as non-technological innovation, including new practices, tools, technical processes and organizational structures adopted by firms to improve the effectiveness of their internal organizational processes. Several studies $[1,15]$ reported positive effects of organizational innovations on innovation capabilities and firm performance.

Despite the importance of innovation for SMEs, there is a lack of research on the actual processes by which these firms undertake innovative activities [16,17]. Some studies (e.g., [11,18,19]) investigated the link between collaboration and innovation in the realm of SMEs. However, despite some attempts (e.g., [20]), the role of interfirm partnerships in the implementation of organizational innovation activities in the SME sector remains underexplored. Therefore, the central question to be answered is: Is there a relationship between the motives of interfirm partnerships and organizational innovation? To achieve this objective, a quantitative cross-sectional research design was adopted, resorting to a questionnaire directed to owners-managers of a sample of SMEs in the automotive sector.

For this study, the automotive sector was chosen not only because of its magnitude and general role in the economy, but also because it is a branch dominated by major research and development efforts and technological innovation (cf. also [21]). Here, interfirm partnerships are very important because of the complexity of vehicles, the shortened life-cycle of products and quality requirements [22]. Furthermore, the vertical range of manufacture is at a low level, meaning that sharing technical information between suppliers and manufacturers is essential [23]. Hence, studying partnerships and organizational innovation among SMEs in the automotive sector is relevant, as it can reveal how these managerial phenomena are interrelated and to what extent they can be complementary.

The remainder of the paper is organized as follows: Section 2 presents a literature review on interfirm partnerships and organizational innovation, resulting in the research hypothesis to be investigated. Section 3 describes the research methods followed in this study. Section 4 analyzes and discusses the data obtained. Finally, Section 5 presents the conclusions and implications, as well as limitations and future lines of research.

\section{Literature Review}

\subsection{Interfirm Partnerships}

According to Contingency Theory [24], an uncertain surrounding environment causes instability within firms. As there is no ideal organizational structure, a firm must know how to adapt to contingency factors and the environment. There are various ways of restructuring and organizing when faced with different emerging situations. In this context, interfirm partnerships are generally seen as a means to sustain firms' development and success [25]. Such partnerships allow the creation of competitive advantages that a single firm cannot achieve alone [26]. Indeed, many researchers came to the conclusion that interfirm partnership leads to better performance by the partners involved (e.g., [27-29]).

An important characteristic of all partnerships is the partners' joint or similar goals when entering into the collaboration [13]. Accordingly, the underlying motivation for partnership formation is the achievement of mutually compatible and/or strategically relevant objectives [12]. In fact, motives to form partnerships are a key dimension for understanding and explaining interfirm partnerships [13]. Such partnerships contribute to reducing and sharing risks, and to increased synergies among firms through the share of resources, information and knowledge [16,30-32].

More specifically, partnerships stimulate the exchange of ideas and the share of competences, facilitating inter-organizational communication, trust and the development of management capacities, innovation and modernization [30,33]. The creation of partnerships also allows the identification of market trends and opportunities [34]. Hence, interfirm partnerships are a means to fill resource 
gaps and obtain additional or complementary resources [35]. Thus, a suitable conceptual basis for explaining partnership formation is Resource-Based Theory [36], which consists of analyzing the position of resources in an organization and looking at strategic options suggested by that analysis.

In the context of SMEs, interfirm partnerships may be particularly helpful in overcoming the lack of internal resources and improving innovativeness and competitiveness [4]. The most frequently cited motives for partnership formation in the SME sector are to gain access to new markets, consolidate market positions, obtain a greater supply of products, gain access to know-how, technology, supplementary production capacities, reduced transaction costs and continuous learning, among other motives [37]. Generally speaking, the motives for partnership formation can be grouped into four aspects: resource, organization, cost and market-related aspects [13]. According to the latter authors, these motives cannot really be separated from each other, as they are interconnected and overlapping concepts.

In the automotive industry, SMEs mainly present difficulties regarding investment costs that prevent them from accompanying clients' demands in terms of innovation [38]. Therefore, one of the aims of interfirm partnership creation is technological innovation, as the complexity of vehicles, diversified knowledge and the shortened life-cycle of products requires absorption and integration of external knowledge [22]. Due to the low vertical range of manufacture, there must be a great amount of sharing between suppliers and manufacturers to create competitive advantages [23]. In turn, the latter need to collaborate with suppliers in the conception and development of vehicles' elements, so there is a mutual need for partnerships. In this context, interfirm partnerships are considered to be a form of open innovation in the automotive industry [22].

\subsection{Organisational Innovation}

Innovation can be categorized in technological and non-technological innovation. However, as pointed out by Damanpour [39], by far the greatest part of research has focused on understanding technological innovations and their economic impact. Only at the end of the 1980s did organizational innovation as non-technological innovation come under scientific scrutiny (e.g., [40]). One of the first examples was the Toyota Production System, which allowed Toyota to become the world's number one car manufacturer [41]. Nevertheless, despite its growing importance, research into this type of innovation has only begun to take its first steps $[10,14]$.

Non-technological forms of innovation have been referred to as administrative innovation (e.g., [42]), management innovation (e.g., [10,39,43]), managerial innovation (e.g., [1,14]) and organizational innovation (e.g., $[15,44,45])$. However, in their comparative study of organizational, administrative and managerial innovation, Damanpour and Aravind [14] ascertained that all three terms are characterized by similar ideas and are often applied synonymously, so that this study uses the term mostly referred to in the literature: organizational innovation.

The concept of organizational innovation compared to non-technological innovations permits a broader innovation concept [46], but is also focused on a different process of innovation. This type of organizational innovation is difficult to imitate, and unique, i.e., firms that use these type of organizational activities can be more competitive [10,39,43]. As noted by Steiber and Alänge [45], organizational innovations can improve a firm's innovation capacity and help to reduce several costs. In addition, some studies found positive effects of organizational innovation on firm performance (e.g., $[1,15])$.

Daft [47] defined organizational innovation as a new idea or behavior put into practice. In addition, organizational innovations lead to changes in management systems, processes and social relations inside the firm $[40,48]$. In this vein, Mustafa [49] described organizational innovation as new forms of leadership and changes in the organizational culture. Armbruster et al. [44] spoke of the application of new principles to the production of goods and services, new structures and operational processes, a new type of relationship between people and behavior models. From this viewpoint, Socio-Technical Theory [50] seems appropriate to explain organizational innovation. This theory combines different 
types of practices and resources resulting from both the technical system on the one hand, and the social system and social relationships of the people involved on the other.

According to the Oslo Manual [51], organizational innovation includes organizational changes over time, as well as new management practices and activities. In addition, this type of innovation requires new knowledge and organizational methods to improve external partnerships. Organizational innovation also refers to altering an organization's internal structure in order to associate it in a network with other surrounding entities such as other firms $[3,52,53]$.

Organizational innovation can emerge from internal and external actors [54], and these partnerships with clients, suppliers and competitors can improve organizational innovation practices [43]. Such innovation activities are particularly relevant in the case of the automotive industry, in which the production system and the markets are constantly changing in response to ecological and quality requirements [22]. In the automotive sector, organization culture is triggering organizational innovation [21], so that studying partnerships with other firms to gain access to organizational innovation is a promising field of research.

\subsection{Research Hypothesis}

Regardless of the importance of the two basic concepts underlying this paper, namely interfirm partnerships and innovation, previous research on their interrelationship brought to light rather mixed outcomes [20]. In their ten-year literature review on innovation-related studies in the manufacturing sector, Becheikh et al. [55] found that research exploring the interface between inter-organizational cooperation and innovation is far from conclusive. By and large, many researchers found that knowledge and information gained from external partnerships leads to better innovation performance (e.g., [34,56]), particularly in the manufacturing industry [32,57,58].

More specifically, positive links were reported with product innovation performance (e.g., [34,59-61]). With regard to SMEs, Nieto and Santamaría [61] analyzed the partnerships of Spanish manufacturing firms and also found that the impact of collaboration in SMEs is more significant for product innovations than for process innovations. Interestingly, a survey of UK manufacturing SMEs conducted by Tomlinson and Fai [19] showed that partnerships facilitate both product and process innovations. However, there are also studies indicating a non-existent or even reverse association between interfirm partnerships and innovation. For example, Freel [62] concluded that inter-organizational cooperation cannot be considered as either a necessary or a sufficient condition for product or process innovation. Hynes and Elwell [63] showed that inter-organizational networks can both enable and delay disruptive technologies.

Regarding the particular link between interfirm cooperation motives and organizational innovation, Pouwels and Koster [20] found a positive and significant relationship analyzing generic data from small, medium-sized and large enterprises in Europe. In light of these arguments, the objective of this study was to scrutinize whether there is a similar effect among SMEs of a specific branch, namely the automotive sector. Consequently, the following research hypothesis was formulated:

Hypothesis 1. The motives of interfirm partnerships affect positively organizational innovation in SMEs in the automotive sector.

\section{Methods}

\subsection{Research Design and Sample}

In order to test the research hypothesis, a quantitative research design was adopted, because the objective was to determine and quantify the relationship between interfirm partnerships formation and organizational innovation. As for the population, a database of SMEs in the automotive sector in Portugal was built. Within automotive sector, we considered also sub-sectors such as automotive materials, parts and supplies, electronics and painting technologies. To do so, data were 
gathered though ANECRA, the National Association of Businesses Dealing in and Repairing Vehicles (www.anecra.pt/info), which is the largest national automotive organization in Portugal.

From the overall population of firms registered in the association, essentially sellers of vehicle parts, repairers and car showrooms were addressed, representing the down-stream level of the automotive value chain. From these firms, those fulfilling the SME criterion in terms of employees established by the European Commission [64] were extracted. In other words, for the database, only the firms with under 250 employees were considered. Afterwards, a random sample using the database of these SMEs was established. As the randomization technique, all SMEs were numbered and MS Excel's random number function was applied. Finally, a random sample was obtained, resulting in 1100 SMEs operating in the automotive sector in Portugal.

\subsection{Data Collection and Measures}

Data for this study were obtained through applying a questionnaire to the randomly selected SMEs in the Portuguese automotive sector. The questionnaire aimed to capture a set of variables underlying the two phenomena under study, namely partnership formation and organizational innovation. Furthermore, the questionnaire gathered data on the sociodemographic characteristics of the respondents, the SMEs and their interfirm partnerships. In order to increase the reliability and content validity of the measuring instrument, established scales were used.

To gather the motives for interfirm partnership formation, the questionnaire included the scales previously used in the studies by Haase and Franco [13], Franco and Haase [37]. These scales have already been applied to SMEs in Portugal. Respondents were asked to rank the importance of these motives through five-point Likert scales, where 1 corresponds to 'Completely disagree' and 5 to 'Completely agree'. To measure organizational innovation, the validated scales of Tsai et al. [65] and Chen and Chang [66] were adopted. Here, statements related to organizational innovation activities were used that respondents also had to evaluate through five-point Likert scales.

After some pre-tests, 1100 questionnaires were sent out by e-mail from February to April 2016, but the initial response rate was low. After a period of 15 days, contact was made by telephone. Following this procedure, 65 valid responses were obtained from SMEs that had established partnerships with other firms, which equals a 5.9 percent response rate. The low response rate may be due to the fact that SMEs find it to be more of a problem to reply to mail questionnaires than larger companies, and the managers in Portuguese SMEs would have only a limited amount of time to devote to the questionnaire. Thus, in order to evaluate the non-response bias, we compared the characteristics of the entire population against the final sample. No significant differences were found for several firms' characteristics such as the age and the number of the employees.

In the survey, a partnership was described as formal or informal agreements with other (independent) firms, in order to attain joint objectives [13]. It is worth noting that firms that have or had more than one partnership were asked to answer the questionnaire while considering only one agreement, the one with greatest strategic importance for the firm.

\subsection{Data Analysis}

For data analysis, at a first stage the sample was characterized through descriptive statistics. Then, Factor Analysis with varimax rotation served to reduce correlational variables into a smaller number of factors. To check the reliability of this multivariate analysis, the Kaiser-Meyer-Olkin (KMO) [67] test of sampling adequacy and Bartlett's test of sphericity were applied. Cronbach's alphas [68] were calculated to measure the internal consistency of the scales composing the extracted factors. Afterwards, ANOVA was run in order to explore differences among the factors extracted. In doing so, the Levene's test assessed the homogeneity of the variances as a precondition of ANOVA.

Finally, to validate the research hypothesis, multiple linear regression was performed. This procedure uses the extracted factors as dependent (organizational innovation) and independent (motives for interfirm partnership formation) variables in order to quantify the relationships among 
the factors. The quality of the regression model was captured by the adjusted $\mathrm{R}^{2}$, which reveals the proportion of variance of the dependent variable explained by the independent variables. Variance Inflation Factors (VIF) and Tolerance Values (T) were calculated as indicators in order to examine potential multicollinearity among the variables of the model.

\section{Results}

\subsection{Sample Characterisation}

The following two tables give a general characterization of the sample. Table 1 characterizes the respondents and the SMEs surveyed, while Table 2 describes the partnerships formed by these firms.

Table 1. Characterization of Respondents.

\begin{tabular}{|c|c|c|}
\hline Characteristics & $\begin{array}{l}n \\
65\end{array}$ & $\begin{array}{c}\% \\
100\end{array}$ \\
\hline \multicolumn{3}{|l|}{ Gender } \\
\hline Male & 59 & 90.8 \\
\hline Female & 6 & 9.2 \\
\hline \multicolumn{3}{|l|}{ Age } \\
\hline 19-35 years & 24 & 36.9 \\
\hline $36-52$ years & 32 & 49.2 \\
\hline 53-69 years & 9 & 13.9 \\
\hline \multicolumn{3}{|l|}{ Position in the firm } \\
\hline Firm director & 4 & 6.2 \\
\hline Manager & 28 & 43.1 \\
\hline Car parts salesperson & 8 & 12.3 \\
\hline Other (e.g., workshop head, mechanical) & 25 & 38.4 \\
\hline \multicolumn{3}{|l|}{ Years of service in the firm } \\
\hline Under 1 year & 8 & 12.3 \\
\hline $1-5$ years & 21 & 32.3 \\
\hline $6-10$ years & 16 & 24.6 \\
\hline More than 10 years & 20 & 30.8 \\
\hline \multicolumn{3}{|l|}{$\mathrm{N}^{\circ}$ Employees } \\
\hline Under 9 & 36 & 55.4 \\
\hline Between 10 and 49 & 20 & 30.8 \\
\hline Between 50 and 250 & 9 & 13.8 \\
\hline \multicolumn{3}{|l|}{ Company direction } \\
\hline Firm founder & 32 & 49.2 \\
\hline Manager & 24 & 36.9 \\
\hline Independent Direction & 2 & 3.1 \\
\hline Other & 7 & 10.8 \\
\hline \multicolumn{3}{|l|}{ Qualification } \\
\hline Basic education & 21 & 32.3 \\
\hline Secondary education & 18 & 27.7 \\
\hline Academic degree & 11 & 16.9 \\
\hline Master & 3 & 4.6 \\
\hline PhD & 7 & 10.8 \\
\hline Others & 5 & 7.7 \\
\hline
\end{tabular}

The majority of SMEs in the sample are micro firms (55.4\%) led by the founder. To classify entrepreneurial units as SME, the number of employees was used as the defining criterion, i.e., fewer than 250 employees. Thus, our sample was also formed by micro firms (less than 10 employees). This segment of firms here is similar for the entire Portuguese entrepreneurial structure. 
Table 2. Characterization of Interfirm Partnerships.

\begin{tabular}{lcc}
\hline Interfirm Partnerships' Characteristics & $\mathbf{n}$ & $\mathbf{\%}$ \\
& $\mathbf{6 5}$ & $\mathbf{1 0 0}$ \\
\hline Type of partner & & \\
Supplier & 15 & 23.0 \\
Supplier and client & 15 & 23.0 \\
Client and complementary firm & 10 & 15.4 \\
$\quad$ Others & 25 & 38.6 \\
Formality of the agreement & & \\
\hline Formal & 27 & 41.6 \\
Informal & 20 & 30.7 \\
Formal and informal & 18 & 27.7 \\
\hline Number of partners & & \\
1 firm & 13 & 20.0 \\
2 firms & 10 & 15.4 \\
3 to 6 firms & 23 & 35.4 \\
7 to 9 firms & 5 & 7.7 \\
More than 10 firms & 14 & 21.5 \\
\hline Geographical Area & & \\
Portugal & 39 & 60.0 \\
Abroad & 10 & 15.4 \\
Portugal and abroad & 16 & 24.6 \\
\hline
\end{tabular}

Concerning the interfirm partnerships formed, the greatest proportion are formal $(41.6 \%)$, and informal agreements (30.7\%) developed essentially with three to six partners. These informal partnerships are developed more through informal channels than in an institutionalized or formalized way [69]. In many cases, these partners are suppliers and/or clients. Concerning partnership characteristics, we also detected different types: co-marketing, distribution and manufacturingrelated partnerships.

\subsection{Systemising Motives for Interfirm Partnership Formation}

Table 3 shows the motives leading SMEs in the automotive sector to form interfirm partnerships and provides descriptive statistics regarding the importance the firms surveyed attribute to these motives. Outstandingly, to 'Consolidate market position' is the main motive for SMEs to engage in partnerships, followed by to 'Achieve competitive advantages' and subsequently to 'Improve quality' and to 'Share resources and competences'. All these motives have means of 4.3 or more on the five-point Likert scale. In the specific branch of the automotive sector, characterized by low production depth, there is a particular need to collaborate between suppliers and manufacturers [23] so that the above-mentioned motives are reasonable. Then again, the two motives with the lowest means were 'Share senior staff and specialists' and 'Facilitate the internationalization process'. Interestingly, difficulties regarding investment costs [38] was not a motive for partnerships highly ranked by the SMEs in the sample.

In order to reduce and systemize the variety of potential motives for interfirm partnership formation identified in the literature, factor analysis was carried out. After rotation extraction and since there were four eigenvalues that were greater than 1 , four factors were retained having loadings above 0.50, which is preferable according to Hair et al. [70]. These four factors together account for 63.25 percent of the total variance. Regarding the KMO value, which needs to be greater than 0.5 for a satisfactory factor analysis [67], the value is 0.817 , indicating a very acceptable quality. In addition, the Bartlett's test is significant for all scales and the factors have a Cronbach alpha above 0.645 , which guarantees high reliability of the psychometric instruments used in this study [68]. The respective results are also included in Table 3. 
Table 3. Factor Analysis of Motives for Interfirm Partnerships.

\begin{tabular}{|c|c|c|c|c|c|c|c|}
\hline & Means & SD & Eigen-Value & $\%$ Variance & $\begin{array}{l}\% \text { Accum. } \\
\text { Variance }\end{array}$ & Loadings & $\begin{array}{l}\text { Cronbach } \\
\text { Alpha }\end{array}$ \\
\hline Factor 1: Efficiency & 3.40 & 0.82 & 3.516 & 19.535 & 19.535 & & 0.850 \\
\hline Share investment costs & 3.600 & 1.1011 & & & & 0.753 & \\
\hline Facilitate the internationalization process & 3.062 & 1.1302 & & & & 0.720 & \\
\hline Create and exploit synergies & 3.892 & 0.9540 & & & & 0.680 & \\
\hline Share and reduce risks & 3.585 & 0.9502 & & & & 0.678 & \\
\hline Reduce transaction costs & 3.277 & 1.1925 & & & & 0.602 & \\
\hline Share senior staff and specialists & 2.969 & 1.1452 & & & & 0.501 & \\
\hline Factor 2: Innovation and learning & 4.16 & 0.62 & 2.947 & 16.375 & 35.910 & & 0.844 \\
\hline Share resources and competences & 4.308 & 0.5842 & & & & 0.835 & \\
\hline Gain experience & 4.000 & 0.8478 & & & & 0.752 & \\
\hline Consolidate market position & 4.385 & 0.6045 & & & & 0.588 & \\
\hline Stimulate a learning process & 3.708 & 1.0857 & & & & 0.560 & \\
\hline $\begin{array}{l}\text { Improve in terms of innovation and } \\
\text { modernization }\end{array}$ & 4.185 & 0.8820 & & & & 0.556 & \\
\hline Improve quality & 4.354 & 0.8184 & & & & 0.501 & \\
\hline Factor 3: Market opportunities & 4.08 & 0.66 & 2.566 & 14.256 & 50.166 & & 0.645 \\
\hline Achieve competitive advantages & 4.369 & 0.7410 & & & & 0.743 & \\
\hline Gain access to new markets & 4.154 & 0.9393 & & & & 0.688 & \\
\hline Create scale economies & 3.708 & 0.8790 & & & & 0.538 & \\
\hline Factor 4: Technology and competition & 3.46 & 0.88 & 2.355 & 13.085 & 63.251 & & 0.720 \\
\hline Respond to competitors' actions & 3.738 & 1.0043 & & & & 0.834 & \\
\hline Technology transfer & 3.523 & 1.1195 & & & & 0.705 & \\
\hline Overcome governmental and regulatory barriers & 3.123 & 1.1793 & & & & 0.648 & \\
\hline
\end{tabular}

$\mathrm{n}=65 ; \mathrm{KMO}=0.817$; Bartlett's Sphericity Test $=580.062 ; \mathrm{gl}=153$; sig. $=0.000$; The mean for individual motives is the average on scale: 1 -very unimportant; 2 -unimportant; 3-indifferent; 4-important; 5-very important. 
The next paragraphs characterize the four factors identified:

Factor 1 'Efficiency' is formed of six variables, referring to the motives for joining interfirm partnerships, such as to 'share investment costs', 'facilitate the internationalization process', 'create and exploit synergies', 'share and reduce risks', 'reduce transaction costs' and 'share senior staff and specialists'. Taken together, this factor covers aspects frequently associated with interfirm partnerships [30]. In addition, it is also through internationalization that sharing of resources and synergies can be achieved [37]. In the specific field of the automotive industry, the mutual sharing of technical information was found to be highly relevant [23]. After calculating the average score of the factor, 'Efficiency' was given a relatively low rank by the responding firms in the sample, presenting a mean of 3.40 .

Factor 2 'Innovation and learning' is also formed of six variables, covering to 'share resources and competences', 'gain experience', 'consolidate market position', 'stimulate a learning process', 'improve in terms of innovation and modernization' and 'improve quality'. Similarly to the first factor extracted, Factor 2 refers to typical motives for firms engaging in partnerships, to promote development of the innovation and modernization process in SMEs $[30,31,33]$. Specifically in the automotive sector, the complexity of vehicles requires high quality to obtain a better position in the market [22]. This factor was found to be the most important motive for partnership formation in the SMEs studied, with a mean of 4.16 .

Factor 3 'Market opportunities' is made up of three underlying motives, namely to 'achieve competitive advantages', 'gain access to new markets' and 'create scale economies'. These motives were also mentioned by Kumar and Subrahmanya [23] for partnership formation in the automobile industry. Regarding the average score of this factor, 'Market Opportunities' was also one of the most prominent motives for interfirm partnership formation.

Factor 4 'Technology and competition' is also formed of three variables, which are to 'respond to competitors' actions', 'technology transfer' and 'overcome governmental and regulatory barriers'. In fact, $\mathrm{Li}$ et al. [30] made an argument for interfirm partnerships to respond better to competitors' actions.

\subsection{Systemising Organisational Innovation}

From the descriptive analysis of organizational innovation activities, Table 4 was developed showing the means and standard deviation values. This analysis shows that 'The firm introduces new techniques to improve operating procedures' was the activity with the greatest importance attributed to by the respondents, followed by 'The firm introduces new, more effective information/communication systems' and 'The firm's new organizational methods promote the capacity to adapt and innovate'. This empirical evidence underscores the fact that even in the automotive sector, both internal and external ideas are needed in order induce organizational innovation activities [71].

In order to identify a relatively restricted number of dimensions that can be used to explain the organizational innovation phenomenon, factor analysis was applied. Table 4 presents the eigenvalue as well as the loadings of the variables underlying organizational innovation. As they are higher than 0.7 , these variables can be grouped in just one factor [70]. This factor accounts for 66.23 percent of the total variance. The KMO value of 0.866 proves the high acceptability of the technique [67]. Moreover, the Bartlett's test is significant and the Cronbach's alpha is largely above 0.7, indicating satisfactory consistency of the scales [68].

As there was only one factor extracted, 'Organizational innovation' is seen here as a unidimensional construct, composed of the six variables appearing in Table 4. It can therefore be confirmed that organizational innovation has to do with increasing employees' efficiency and satisfaction so as to improve the organization's innovative capacity [45]. Moreover, corporate culture seems to be important for organizational innovation in the automotive sector, which underpins the findings of Chaubey and Sahoo [21]. 
Table 4. Factor Analysis of Organizational Innovation.

\begin{tabular}{|c|c|c|c|c|c|c|c|}
\hline & Means & SD & Eigen-Value & $\begin{array}{c}\% \\
\text { Variance }\end{array}$ & $\begin{array}{l}\text { \% Accum. } \\
\text { Variance }\end{array}$ & Loadings & $\begin{array}{c}\text { Cronbach } \\
\text { Alpha }\end{array}$ \\
\hline $\begin{array}{l}\text { Factor 1: Organizational } \\
\text { Innovation }\end{array}$ & 3.81 & 0.72 & 3.974 & 66.230 & 66.230 & & 0.890 \\
\hline $\begin{array}{l}\text { 1. The firm created a new } \\
\text { culture of innovation }\end{array}$ & 3.667 & 0.9069 & & & & 0.864 & \\
\hline $\begin{array}{l}\text { 2. The firm's new } \\
\text { organizational methods } \\
\text { promote the capacity to } \\
\text { adapt and innovate }\end{array}$ & 3.852 & 0.8627 & & & & 0.858 & \\
\hline $\begin{array}{l}\text { 3. The firm introduces new } \\
\text { techniques to improve } \\
\text { operating procedures }\end{array}$ & 4.056 & 0.7082 & & & & 0.857 & \\
\hline $\begin{array}{l}\text { 4. The firm introduces new, } \\
\text { more effective } \\
\text { information/communication } \\
\text { systems }\end{array}$ & 3.981 & 0.8645 & & & & 0.804 & \\
\hline $\begin{array}{l}\text { 5.The firm uses new } \\
\text { organizational methods to } \\
\text { motivate subordinates }\end{array}$ & 3.630 & 1.0009 & & & & 0.770 & \\
\hline $\begin{array}{l}\text { 6. The firm develops } \\
\text { management practices } \\
\text { according to changes } \\
\text { occurring in the market }\end{array}$ & 3.685 & 1.0290 & & & & 0.720 & \\
\hline
\end{tabular}

\subsection{Influence of Interfirm Partnerships on Organisational Innovation}

In the next step of the analysis, ANOVA served to explore whether there is a significant difference among the extracted factors. The Levene's test assessing the equality of variances was not significant, so the variances among the factors are homogeneous and ANOVA can be used as the appropriate procedure. Table 5 presents the results of the ANOVA, showing a statistically very robust difference among the factors.

Table 5. ANOVA.

\begin{tabular}{cccccc}
\hline & Sum Sq & Df & Mean Sq & F & Sig \\
\hline Treatments & 11.927 & 4 & 2.982 & 7.925 & $0.000 * * *$ \\
Residual Error & 22.575 & 60 & 0.376 & & \\
Total & 34.502 & 64 & & & \\
\hline
\end{tabular}

$\mathrm{n}=65 \overline{;}^{* * *} p<0.01$; Independent variables: Motives for interfirm partnerships; Dependent variable: Organizational innovation.

However, the ANOVA does not indicate where exactly the differences among the factors regarding the dependent variable lie. As a suitable technique to test the research hypothesis assuming that the formation of interfirm partnerships is positively related with 'Organizational innovation' in SMEs in the automotive sector, a multiple linear regression analysis was performed. In this analysis, the four motives explaining interfirm partnership formation act as independent variables and 'Organizational innovation' as the dependent variable. These variables/factors were converted to single measures using average summated scores.

By computing the regression model shown in Table 6, multicollinearity was also assessed. The VIF values for the sample are under the recommended cut-off level of 5 and the T values are above 0.1 [72,73], which indicates that the four factors extracted are only moderately correlated, i.e., they are largely independent of each other. Hence, multicollinearity does not affect the results of the linear regression model. The outcomes of the multiple linear regression analysis reveal, on the one hand, that only 
the motives for implementing interfirm partnerships associated with the 'Technology and competition' factor show a positive and significant relationship with 'Organizational innovation' $(\beta=0.510, p<0.01)$. Hence, the research hypothesis can only partially be rejected.

Table 6. Multiple Linear Regression.

\begin{tabular}{ccccc}
\hline & $\boldsymbol{\beta}$ & Sig & VIF & T \\
\hline Efficiency & 0.38 & 0.806 & 2.235 & 0.447 \\
Innovation and learning & -0.065 & 0.670 & 2.138 & 0.468 \\
Market opportunities & 0.161 & 0.253 & 1.782 & 0.561 \\
Technology and & 0.510 & $0.000 * * *$ & 1.557 & 0.642 \\
competition & 7.925 & & & \\
$\mathrm{~F}$ & 0.000 & & & \\
$p$ & 0.346 & & \\
$\mathrm{R}^{2}$ & 0.302 & & \\
Adjusted & $\mathrm{R}^{2}$ & & & \\
$\mathrm{n}=65 ; * * * p<0.01 ;$ Independent variables: & Motives for interfirm partnerships; Dependent variable: \\
Organizational innovation. &
\end{tabular}

On the other hand, motives underlying partnership formation related to 'Efficiency', 'Innovation and learning' and 'Market opportunities' were not confirmed to have an influence on 'Organizational innovation' among the SMEs in our sample. This lack of relationship can be explained by the fact that the automotive sector is highly technological and the complexity of vehicles means firms have to find strategies to overcome technology-related resource constraints in order to ensure their competitiveness.

In sum, our nuclear hypothesis, that the motives of interfirm partnerships positively affect organizational innovation in SMEs in the automotive sector, was partially supported.

\section{Discussion}

The formation of interfirm partnerships has been suggested as a viable strategy to strengthen innovativeness and competitiveness in SMEs [4]. Facing limitations in terms of size, structure and finance, SMEs can rely on interfirm partnerships in order to overcome these disadvantages. Therefore, the main objective of this study was to examine the influence of interfirm partnership motives on implementation of organizational innovation activities in SMEs in the Portuguese automotive sector.

Based on the empirical evidences, we conclude that the most frequently indicated motives for partnership formation in the SMEs studied here is to 'Consolidate market position', 'Achieve competitive advantages', 'Improve quality' and 'Share resources and competences'. These motives and others for forming interfirm partnerships highlighted by the respondents show the need to share and constantly update information so that SMEs in the automotive sector can remain in the market and even branch out beyond national boundaries. The variety of motives underlying partnership formation were categorized in four factors 'Efficiency', 'Innovation and learning', 'Market opportunities', 'Technology and competition'.

The results obtained also suggest that interfirm partnership formation is linked with the implementation of organizational innovation activities, which is in line with Mol and Birkinshaw [43] and Pouwels and Koster [20]. However, the effect is only partial, as of the four factors of motives for partnership formation extracted, only 'Technology and Competition' showed a positive and significant relationship with organizational innovation. The introduction of new techniques to improve operating procedures was the main motive for the SMEs in the sample implementing organizational innovation. As the sector under scrutiny is a technological sector, 'Technology and Competition' as a motive for engaging in interfirm partnerships is consequently linked with organizational innovation activities.

As organizational innovation covers the implementation of new methods both internally and externally, partnerships with other firms in order to access new technology can be an important strategic instrument. With 'technology and competition' as the decisive factor, the outcomes of this research are 
in line, at least partially, with the findings of Pouwels and Koster [20], and specify the relationship between interfirm cooperation and organizational innovation for SMEs in the automotive sector.

Moreover, if the SME introduces new techniques through interfirm partnerships to improve its operational procedures and introduces new, more effective information/communication systems, this leads to successful organizational innovation. As stated by Drejer [71], without these internal and external alterations, organizational innovation in the automotive sector is jeopardized. Although inter-organizational cooperation may sometimes be harmful specifically for disruptive technologies [63], such an effect is very unlikely to occur in the automotive industry because it is commonly characterized by sustaining technologies, based on incremental innovation and the gradual development of the existing state-of-the-art. In such environments, interfirm partnerships pursuing technology and responding to competition seem to be highly relevant.

\section{Implications and Future Research Avenues}

This study presents implications for theory and practice. In terms of theory, it contributes to understanding the role of interfirm partnerships in the implementation of innovation activities in the SME sector. To date, only a few studies (e.g., [18-20,61]) have addressed this issue. This study pursues a new approach applying variables related to partnership motives in general, and among SMEs in particular.

Another novel contribution of our study is associated with the relevance of the context in which this study takes place. SMEs in the automotive sector is an innovative context studied in interfirm partnerships and organizational innovation. This study is one of the first studies that empirically investigating how interfirm partnership motives can be seen as a mechanism for organizational innovation. In fact, the results of our analysis may be of interest to academics and researchers that want to go further in developing a consolidated model that explains organizational innovation in this particular sector. Therefore, our results make an empirical contribution to the study of interfirm partnerships motives in a specific economic, cultural and geographical context: Portuguese firms where the majority are SME. We focused also on a particular sector (automotive) where interfirm partnerships can be particularly useful, but where such engagement also implies particular threats. Furthermore, specific scales regarding the motives for interfirm partnership formation and the organizational innovation process were also implemented and combined in this specific context of analysis.

In practical terms, the results show the extent to which the motives for interfirm partnership implementation, such as those connected to technology and competition, have a strong influence on organizational innovation activities and, therefore, our study increased relevance to the business environment and policy makers. This research is also relevant because the SME sector is dominated by owner-managers with idiosyncratic characteristics and behavior. Therefore, the study should make those in charge of SMEs in the automotive sector aware of the need to form interfirm partnerships and how this strategy can influence innovation in organizational terms.

This paper provides also several insights and policy implications for managers and practitioners, in terms of interfirm partnerships and organizational innovation. From the results obtained, we suggest the actors and SMEs involved in automotive sector should reinforce more interaction and articulation between the various partners, so as to generate synergies. In addition, to remain competitive and sustainable, automotive SMEs aiming for rapid growth should focus on exploiting opportunities in external partners, with a view to consolidating their position there. To this end, the pooling of resources and/or contributing complementary knowledge and skills via partnerships are important strategic instruments, providing a set of opportunities that allow us to develop innovation activities. The benefits are the development of innovative products, spreading product awareness, forms of sharing risks, reducing costs through synergies and increasing scale. Considering that a lack of resources is one of the most common characteristics presented by SMEs, forming interfirm partnerships can be important in overcoming this need. 
This research is not without limitations. The most important limitation concerns the low response rate received in the survey. The limited number of responses can be explained by the fact that the automotive branch in Portugal sometimes seems to be still very 'self-contained', with some entities being rather unconcerned about what lies 'outside' their firm. So replication with a different sample, ideally a larger one, is necessary if results are to be generalized. Furthermore, the study relies on self-report responses to a questionnaire, which implies subjective components and may result in auto-evaluation bias. In addition, taking into account the number of variables of the questionnaire, this restricts the statistical power of the factorial analyses that were performed. Another limitation of this study is that it takes the perspective of only one partner-a limitation common to most interfirm partnerships research. Thus, for further studies in this research area, it is necessary to analyze each side of the partnership.

Regarding the research implications arising from the findings and limitations, it is also suggested to extend this study to other sectors of activity, and not only focus on SMEs. It would also be interesting to extend the research to other geographical areas (other countries) in order to detect potential differences and allow comparisons. Moreover, studies adopting another type of methodological approach, for example, qualitative research (case studies) is also recommended as a future line of research for better understanding of certain details of this phenomenon, which was not possible through the quantitative method employed here.

Author Contributions: M.F. had the initial idea of the manuscript and wrote an original draft and also provided the resources for the research, and H.H. participated in the formal reviews and supervision. All authors have read and agreed to the published version of the manuscript.

Funding: This research was not funded.

Acknowledgments: The authors are grateful to the anonymous referees of the journal for their extremely useful suggestions to improve the quality of the paper. The authors gratefully acknowledge financial support from National Funds of the FCT-Portuguese Foundation for Science and Technology within the project «UIDB/04007/2020».

Conflicts of Interest: The authors declare no conflict of interest.

\section{References}

1. Woschke, H.; Haase, T. Enhancing new product development capabilities of small- and medium-sized enterprises through managerial innovations. J. High Technol. Manag. Res. 2016, 27, 53-64. [CrossRef]

2. Christensen, C.M. The Innovator's Dilemma: When New Technologies Cause Great Firms to Fail; Harvard Business Review Press: Boston, MA, USA, 2013.

3. Ode, E.; Ayavoo, R. The mediating role of knowledge application in the relationship between knowledge management practices and firm innovation. J. Innov. Knowl. 2020, 5, 209-217. [CrossRef]

4. Hewitt-Dundas, N. Resource and capability constraints to innovation in small and large plants. Small Bus. Econ. 2006, 26, 257-277. [CrossRef]

5. Madrid-Guijarro, A.; Garcia, D.; van Auken, H. Barriers to innovation among Spanish manufacturing SMEs. J. Small Bus. Manag. 2009, 47, 465-488. [CrossRef]

6. Aldrich, H.; Auster, E. Even Dwarfs Started Small: Liabilities of age and size and their strategic implications. In Research in Organizational Behaviour; Stawm, B.M., Cummings, L.L., Eds.; JAI Press: Greenwich, CT, USA, 1986; Volume 8, pp. 165-198.

7. Baum, J.; Oliver, C. Institutional linkages and organizational mortality. Adm. Sci. Q. 1991, 36, 187-218. [CrossRef]

8. Gonçalves Silveira Fiates, G.; Azevedo Fiates, A.; Ribeiro Serra, F.A.; Portugal Ferreira, M. Innovation environment in small technology-based companies. J. Technol. Manag. Innov. 2010, 5, 81-95. [CrossRef]

9. Laforet, S. Organizational innovation and outcomes in SMEs. In Organizational Culture, Business-to-Business Relationships, and Interfirm Networks, Advances in Business Marketing and Purchasing; Woodside, A.G., Ed.; Emerald Group: Bingley, UK, 2010; Volume 16, pp. 341-362.

10. Volberda, H.W.; van den Bosh, F.A.; Heij, C.V. Management innovation: Management as fertile ground for innovation. Eur. Manag. Rev. 2013, 10, 1-15. [CrossRef] 
11. Nieto, M.J.; Santamaría, L. Technological collaboration: Bridging the innovation gap between small and large firms. J. Small Bus. Manag. 1990, 48, 44-69. [CrossRef]

12. Culpan, R. A fresh look at strategic alliances: Research issues and future directions. Int. J. Strateg. Bus. Alliances 2009, 1, 4-23. [CrossRef]

13. Franco, M.; Haase, H. Interfirm alliances: A taxonomy for SMEs. Long Range Plan. 2015, 48, $168-181$. [CrossRef]

14. Damanpour, F.; Aravind, D. Managerial innovation: Conceptions, processes, and antecedents. Manag. Organ. Rev. 2012, 8, 423-454. [CrossRef]

15. Camisón, C.; Villar-López, A. Organizational innovation as an enabler of technological innovation capabilities and firm performance. J. Bus. Res. 2014, 67, 2891-2902. [CrossRef]

16. Noh, H.; Lee, S. Perceptual factors affecting the tendency to collaboration in SMEs: Perceived importance of collaboration modes and partners. J. Technol. Manag. Innov. 2015, 10, 18-31. [CrossRef]

17. Duarte Alonso, A.; Bressan, A. Micro and small business innovation in a traditional industry. Int. J. Innov. Sci. 2016, 8, 311-330. [CrossRef]

18. Kang, K.-N.; Park, H. Influence of government R\&D support and inter-firm collaborations on innovation in Korean biotechnology SMEs. Technovation 2012, 32, 68-78.

19. Tomlinson, P.R.; Fai, F.M. The nature of SME co-operation and innovation: A multi-scalar and multidimensional analysis. Int. J. Prod. Econ. 2013, 141, 316-326. [CrossRef]

20. Pouwels, I.; Koster, F. Inter-organizational cooperation and organizational innovativeness. A comparative study. Int. J. Innov. Sci. 2017, 9, 184-204. [CrossRef]

21. Chaubey, A.; Sahoo, C.K. Enhancing organizational innovation in Indian automobile industry. Int. J. Innov. Sci. 2019, 11, 82-101. [CrossRef]

22. Dodourova, M.; Bevis, K. Networking innovation in the European car industry: Does the Open Innovation model fit? Transp. Res. Part A Policy Pract. 2014, 69, 252-271. [CrossRef]

23. Kumar, S.R.; Subrahmanya, B.H. Influence of subcontracting on innovation and economic performance of SMEs in Indian automobile industry. Technovation 2010, 30, 558-569. [CrossRef]

24. Donaldson, L. The Contingency Theory of Organizations, Foundations for Organizational Science; Sage Publications: Thousand Oaks, CA, USA, 2001.

25. Shah, R.H.; Swaminathan, V. Factors influencing partner selection in strategic alliances: The moderating role of alliance context. Strateg. Manag. J. 2008, 29, 471-494. [CrossRef]

26. Clements, M.; Dean, D.; Cohen, D. Proposing an operational classification scheme for embryonic cooperative relationships. J. Manag. Organ. 2007, 13, 51-65. [CrossRef]

27. Spence, M.M.; Mannin, L.M.; Crick, D. An investigation into the use of collaborative ventures in the internationalisation of high performing Canadian SMEs. Eur. Manag. J. 2008, 26, 412-428. [CrossRef]

28. Ritala, P.; Hallikas, J.; Sissonen, H. The effect of strategic alliances between key competitors on firm performance. Manag. Res. 2008, 6, 179-187. [CrossRef]

29. Robson, M.J.; Katsikeas, C.S.; Bello, D.C. Drivers and performance outcomes of trust in international strategic alliances: The role of organizational complexity. Organ. Sci. 2008, 19, 647-668. [CrossRef]

30. Li, L.; Qian, G.; Qian, Z. Do partners in international strategic alliances share resources, costs, and risks? J. Bus. Res. 2013, 66, 489-498. [CrossRef]

31. Bouncken, R.; Pesch, R.; Gudergan, S. Strategic embeddedness of modularity in alliances: Innovation and performance implications. J. Bus. Res. 2015, 68, 1388-1394. [CrossRef]

32. Hui, Z.; He-Cheng, W.; Min-Fei, Z. Partnership management, supply chain collaboration, and firm innovation performance: An empirical examination. Int. J. Innov. Sci. 2015, 7, 127-138. [CrossRef]

33. Albers Mohrman, S.; Tenkasi, R.V.; Mohrman, A.M. The role of networks in fundamental organisational change: A grounded analysis. J. Appl. Behav. Sci. 2003, 39, 301-323. [CrossRef]

34. Tsai, K.H. Collaborative networks and product innovation performance: Toward a contingency perspective. Res. Policy 2009, 38, 765-778. [CrossRef]

35. Teng, B.S. Corporate entrepreneurship activities through strategic alliances: A resource-based approach towards competitive advantage. J. Manag. Stud. 2007, 44, 119-142. [CrossRef]

36. Wernerfelt, B. A resource-based view of the firm. Strateg. Manag. J. 1984, 5, 171-180. [CrossRef]

37. Haase, H.; Franco, M. An exploratory study of the motives and perceived effectiveness of international cooperative alliances among SMEs. Int. J. Entrep. Innov. Manag. 2011, 13, 314-336. [CrossRef] 
38. Lazzarotti, V.; Manzini, R.; Pellegrini, L.; Pizzurno, E. Open Innovation in the automotive industry: Why and How? Evidence from a multiple case study. Int. J. Technol. Intell. Plan. 2013, 9, 37-56. [CrossRef]

39. Damanpour, F. Footnotes to research on management innovation. Organ. Stud. 2014, 35, 1265-1285. [CrossRef]

40. Damanpour, F.; Szabat, K.A.; Evan, W.M. The relationship between types of innovation and organisational performance. J. Manag. Stud. 1989, 26, 587-602. [CrossRef]

41. Ohno, T. Toyota Production System: Beyond Large Scale Production; Productivity Press: Portland, OR, USA, 1988.

42. Lin, C.Y.; Chen, M.Y. Does innovation lead to performance? An empirical study of SMEs in Taiwan. Manag. Res. News 2007, 30, 115-132.

43. Mol, M.J.; Birkinshaw, J. The sources of management innovation: When firms introduce new management practices. J. Bus. Res. 2009, 62, 1269-1280. [CrossRef]

44. Armbruster, H.; Bikfalvi, A.; Kinkel, S.; Lay, G. Organisational innovation: The challenge of measuring non-technical innovation in large-scale surveys. Technovation 2008, 28, 644-657. [CrossRef]

45. Steiber, A.; Alänge, S. Organizational innovation: A comprehensive model for catalyzing organizational development and change in a rapidly changing world. Triple Helix 2015, 2, 1-25. [CrossRef]

46. Lhuillery, S. Marketing and persistent innovation success. Econ. Innov. New Technol. 2014, 23, 517-543. [CrossRef]

47. Daft, R.L. A dual-core model of organizational innovation. Acad. Manag. J. 1978, 21, 193-210.

48. Tanninen, K.; Jantunen, A.; Saksa, J.-M. Adoption of administrative innovation within organizationAn empirical study of TQM metamorphosis. Int. J. Innov. Technol. Manag. 2008, 5, 321-340. [CrossRef]

49. Mustafa, H.H. The role of ICT management to achieve organizational innovation. Int. J. Organ. Innov. 2015, 7, 48-56.

50. Emery, F.E.; Trist, E.L. Socio-technical systems. In Management Science, Models and Techniques; Churchman, C.W., Verhulst, M., Eds.; Pergamon: New York, NY, USA, 1960; Volume 2, pp. 83-97.

51. OECD. Oslo Manual-Guidelines for Collecting and Interpreting Innovation Data, 3rd ed.; OECD Publishing: Paris, France, 2005.

52. Brettel, M.; Cleven, N.J. Innovation culture, collaboration with external partners and NPD performance. Creat. Innov. Manag. 2011, 20, 253-272. [CrossRef]

53. Tomlinson, P.R. Co-operative ties and innovation: Some new evidence for UK manufacturing. Res. Policy 2010, 39, 762-775. [CrossRef]

54. Birkinshaw, J.; Hamel, G.; Mol, M.J. Management innovation. Acad. Manag. Rev. 2006, 26, 644-664.

55. Becheikh, N.; Landry, R.; Amara, N. Lessons from innovation empirical studies in the manufacturing sector: A systematic review of the literature from 1993-2003. Technovation 2008, 33, 825-845. [CrossRef]

56. Ferraris, A.; Santoro, G.; Dezi, L. How MNC's subsidiaries may improve their innovative performance? The role of external sources and knowledge management capabilities. J. Knowl. Manag. 2017, 21, 540-552. [CrossRef]

57. Cassiman, B.; Veugelers, R. In search of complementarity in innovation strategy: Internal R\&D and external knowledge acquisition. Manag. Sci. 2006, 52, 68-82.

58. Laursen, K.; Salter, A. Open for innovation: The role of openness in explaining innovation performance among UK manufacturing firms. Strateg. Manag. J. 2006, 27, 131-150. [CrossRef]

59. Antolín-López, R.; Martínez-del-Río, J.; Céspedes-Lorente, J.J.; Pérez-Valls, M. The choice of suitable cooperation partners for product innovation: Differences between new ventures and established companies. Eur. Manag. J. 2015, 33, 472-484. [CrossRef]

60. Atalay, M.; Dirlik, O.; Sarvan, F. Impact of multilevel strategic alliances on innovation and firm performance: Evidence from the yacht-building industry in Turkey. Int. J. Innov. Sci. 2017, 9, 53-80. [CrossRef]

61. Nieto, M.J.; Santamaría, L. Technological collaboration: Bridging the innovation gap between small and large firms. J. Small Bus. Manag. 2010, 48, 44-69. [CrossRef]

62. Freel, M.S. Sectoral patterns of small firm innovation, networking and proximity. Res. Policy 2003, 32, 751-770. [CrossRef]

63. Hynes, N.; Elwell, A.D. The role of inter-organizational networks in enabling or delaying disruptive innovation: A case study of mVoIP. J. Bus. Ind. Mark. 2016, 31, 722-731. [CrossRef]

64. European Commission. Commission recommendation of 6 May 2003 concerning the definition of micro, small and medium-sized enterprises. Off. J. Eur. Union 2003, 361, 36-41. 
65. Tsai, C.T.; Huang, K.L.; Kao, C.F. The relationships among organisational factors, creativity of organisational members and organisational innovation. Manag. Rev. 2001, 18, 527-566.

66. Chen, T.S.; Chang, G.B. The effects of absorptive capacity and decision speed on organisational innovation: A study of organisational structure as an antecedent variable. Contemp. Manag. Res. 2012, 8, 27-50. [CrossRef]

67. Kaiser, H.F. An Index of factorial simplicity. Psychometrika 1974, 39, 31-36. [CrossRef]

68. Cronbach, L. Coefficient alpha and the internal structure of tests. Psychometrika 1951, 16, 297-334. [CrossRef]

69. Galan-Muros, V.; Davey, T. The UBC ecosystem: Putting together a comprehensive framework for university-business cooperation. J. Technol. Transf. 2019, 44, 1311-1346. [CrossRef]

70. Hair, J.F.; Black, W.C.; Babin, B.J.; Anderson, R.E.; Tatham, R.L. Multivariate Data Analysis; Pearson Prentice Hall: Upper Saddle River, NJ, USA, 2010.

71. Drejer, I. Identifying innovation in surveys of services: A Schumpetarian perspective. Res. Policy 2004, 33, 551-562. [CrossRef]

72. Rogerson, P.A. Statistical Methods for Geography: A Student's Guide; Sage: London, UK, 2001.

73. O'Brien, R.M. A caution regarding rules of thumb for variance inflation factors. Qual. Quant. 2007, 41, 673-690. [CrossRef]

Publisher's Note: MDPI stays neutral with regard to jurisdictional claims in published maps and institutional affiliations.

(C) 2020 by the authors. Licensee MDPI, Basel, Switzerland. This article is an open access article distributed under the terms and conditions of the Creative Commons Attribution (CC BY) license (http://creativecommons.org/licenses/by/4.0/). 